\title{
WPŁYW REGULACJI UNII EUROPEJSKIEJ NA PRAWO POKRZYWDZONEGO DO POMOCY TŁUMACZA W POLSKIEJ PROCEDURZE KARNEJ
}

\section{Uwagi wstępne}

Zgodnie z art. $2 \S 1$ pkt 3 k.p.k. jednym z podstawowych celów postępowania karnego jest uwzględnienie prawnie chronionych interesów pokrzywdzonego. Nakaz uwzględnienia interesów pokrzywdzonego znajduje odzwierciedlenie w wielu regulacjach szczegółowych k.p.k., wśród których na wyraźne podkreślenie zasługuje przepis art. $299 \S 1$. Wzmocnieniu pozycji pokrzywdzonego służą także regulacje m.in. art. $55 \S 1$, art. 159, art. 318, czy art. $321 \S 5 \mathrm{w}$ zw. z art. 299 § 1 k.p.k. ${ }^{1}$

Chociaż z przepisów art. 4 Ustawy z dnia 7 października 1999 r. o języku polskim $^{2}$ i art. $5 \S 1$ ustawy z dnia 27 lipca 2001 r. Prawo o ustroju sądów powszechnych $^{3}$ wynika, że językiem urzędowym przed organami wymiaru sprawiedliwości jest język polski, w związku z dynamicznym rozwojem stosunków międzynarodowych, coraz częściej w postępowaniu przed polskimi sądami udział biorą cudzoziemcy, którzy nie posługują się językiem polskim w stopniu wystarczającym, aby uczestniczyć w postępowaniu w nim prowadzonym. I, jak słusznie wskazuje R. Stefański ${ }^{4}$, zarówno porozumiewanie się z tymi osobami, jak i korzystanie z dokumentów sporządzonych w innych językach, wymagają udziału tłumacza. J. Długosz zauważa wręcz, że udział ten stał się już pewną rutyną̧

1 A. Sakowicz, (w:) K. Boratyńska, A. Górski, A. Sakowicz, A. Ważny, Kodeks postępowania karnego. Komentarz, Warszawa 2014, s. 10-11.

2 Ustawa z dnia 7 października 1999 r. o języku polskim, Dz.U. z 1999 r. Nr 90, poz. 999, tj. z dnia 2 lutego 2011 r., Dz.U. $2011 \mathrm{Nr}$ 43, poz. 224

3 Ustawa z dnia 27 lipca 2001 r. Prawo o ustroju sądów powszechnych, Dz.U. z 2001 r. Nr 98, poz. 1070, tj. z dnia 30 stycznia 2013 r., Dz.U. z 2013 r., poz. 427.

$4 \quad$ R. Stefański, Udział tłumacza w postępowaniu karnym jako przejaw rzetelnego procesu, (w:) J. Skorupka (red.), Rzetelny proces karny. Księga Jubileuszowa Profesor Zofii Świdy, Warszawa 2009, s. 360.

5 Zob. J. Długosz, Prawo do udziału tłumacza jako jedna z przesłanek rzetelnego procesu karnego, „Investigationes Linguisticae" 2009, vol. XVII - dostępny na stronie internetowej Uniwersytetu im. Adama Mickiewicza w Poznaniu: www.amu.edu.pl 
Pomoc thumacza ma na celu zagwarantowanie prawa do rzetelnego procesu, które przewiduje zarówno Konstytucja $\mathrm{RP}^{6}$ (art. 45), jak i akty prawa międzynarodowego, w tym zwłaszcza Konwencja o ochronie praw człowieka i podstawowych wolności ${ }^{7}$, Międzynarodowy Pakt Praw Obywatelskich i Politycznych ${ }^{8}$ oraz Karta Praw Podstawowych Unii Europejskiej ${ }^{9}$. Jak zauważa M. Rogalski ${ }^{10}$, w doktrynie polskiej uznaje się prawo do rzetelnego procesu za zasadę naczelną procesu karnego. Wskazuje się także, że proces karny powinien być rzetelny również względem osoby pokrzywdzonej ${ }^{11}$.

Celem niniejszego opracowania jest przedstawienie, czy i jaki wpływ regulacje Unii Europejskiej wywarły na prawo pokrzywdzonego do pomocy tłumacza w polskiej procedurze karnej.

\section{Prawo do pomocy tłumacza w regulacjach Unii Europejskiej}

Problematyka udziału tłumacza w postępowaniu karnym zajmuje ważne miejsce w regulacjach UE. Wskazuje się, że w związku z usunięciem granic wewnętrznych i swobodą przemieszczania się, coraz więcej osób bierze udział w postępowaniach karnych w państwie członkowskim innym niż państwo, z którego pochodzą lub w którym mieszkają. Ponadto, w związku ze swobodnym przepływem osób, zwiększa się także liczba przypadków transgranicznych, gdy ofiarami przestępstw stają się obywatele państwa członkowskiego UE, przebywający poza jego granicami ${ }^{12}$. W takich sytuacjach istnieje potrzeba zagwarantowania tym osobom prawa do rzetelnego procesu, którego nieodłącznym elementem jest prawo do pomocy tłumacza.

Jednym z priorytetów działania UE w obszarze wymiaru sprawiedliwości jest stworzenie skutecznych mechanizmów ochrony i pomocy ofiarom przestępstw. Stąd też w 2001 r. przyjęto Decyzję Ramową Rady w sprawie pozycji ofiar w postępowaniu karnym ${ }^{13,14}$, która nie zawierała jednak bezpośredniego odniesienia do prawa

Konstytucja Rzeczypospolitej Polskiej z dnia 2 kwietnia 1997 r., Dz.U. z 1997 r. Nr 78, poz. 483.

Konwencja o ochronie praw człowieka i podstawowych wolności z dnia 4 listopada 1950 r., Dz.U. z 1993 r. Nr 61, poz. 284.

Międzynarodowy Pakt Praw Obywatelskich i Politycznych z dnia 19 grudnia 1966 r., Dz.U. z 1977 r. Nr 38, poz. 167.

Karta Praw Podstawowych Unii Europejskiej z dnia 30 marca 2010 r., Dz.U. UE C 83 z 30.3.2010 r., s. 391-407.

Zob. M. Rogalski, Res iudicata i zakaz ne bis in idem jako gwarancje rzetelnego procesu (w:) J. Skorupka (red.), Rzetelny proces karny. Księga Jubileuszowa Profesor Zofii Świdy, Warszawa 2009, s. 169.

Zob. np. A. Sakowicz, (w:) K. Boratyńska, A. Górski, A. Sakowicz, A. Ważny, op. cit., s. 10.

Stanowisko RP przygotowane w związku z art. 7 ustawy z dnia 8 października 2010 r. o współpracy Rady Ministrów z Sejmem i Senatem w sprawach związanych z członkostwem Rzeczypospolitej Polskiej w Unii Europejskiej, Dz.U. z 2010 r. Nr 213, poz. 1395, dotyczącym Dyrektywy Parlamentu Europejskiego i Rady ustanawiającej normy minimalne w zakresie praw, wsparcia i ochrony ofiar przestępstw - dostępne na oficjalnej stronie internetowej Ministerstwa Sprawiedliwości - www.ms.gov.pl

Decyzja Ramowa Rady 2001/220/WSiSW z dnia 15 marca 2001 r. w sprawie pozycji ofiar w postępowaniu karnym, Dz.U. UE L 82 z 22.03.2001 r., s. 72-75.

Jeszcze przed przyjęciem Decyzji podjęto szereg inicjatyw i działań mających na celu ochronę ofiar przestępstw, $\mathrm{np}$. Plan działania Rady i Komisji w sprawie sposobu najlepszego wdrożenia postanowień Traktatu Amsterdamskiego w przestrzeni wolności, bezpieczeństwa i sprawiedliwości, Tekst przyjęty przez Radę do spraw Wymiaru 
do tłumaczenia. Nałożono jedynie na państwa obowiązek zapewnienia ofiarom, od pierwszego kontaktu z organami ścigania, dostępu do informacji mających znaczenie dla ochrony ich interesów „w językach powszechnie rozumianych” (art. 4). Kolejny dokument dotyczący ofiar przestępstw - dyrektywa z 2004 r. $^{15}$ - również nie podniósł kwestii uprawnienia pokrzywdzonego do pomocy tłumacza.

28 kwietnia 2004 r. Komisja Wspólnot Europejskich przedstawiła Propozycję Decyzji Ramowej Rady w sprawie niektórych praw proceduralnych w postępowaniu karnym w Unii Europejskiej ${ }^{16}$, gdzie określono 5 podstawowych obszarów, w których wspólne minimalne standardy powinny być zastosowane w pierwszej kolejności; wśród nich wymieniono ,prawo do usług w zakresie interpretacji i tłumaczenia, zapewniające, że osoby wymagające szczególnej uwagi, gdyż nie są w stanie śledzić przebiegu postępowania, otrzymają taką uwagę" "17. Jednak, pomimo trwających trzy lata dyskusji, nie osiągnięto porozumienia i wniosek Komisji ostatecznie zarzucono w czerwcu $2007 \mathrm{r}$.

30 listopada 2009 r. Rada UE przyjęła rezolucję ${ }^{18}$, w której wezwano do przyjmowania środków dotyczących prawa do tłumaczenia pisemnego i ustnego. Harmonogram działań ${ }^{19}$, stanowiący załącznik do rezolucji, zawierał wezwanie do stopniowego przyjmowania 6 środków ułatwiających ściganie, a jako pierwszy z nich wymieniono thumaczenia pisemne i ustne. Jednak zapis ten dotyczył jedynie osób podejrzanych lub oskarżonych, pomijając uprawnienie pokrzywdzonego. Harmonogram został następnie ujęty w Programie Sztokholmskim ${ }^{20}$ przyjętym dnia 10 grudnia 2009 r., mającym na celu zapewnienie harmonogramu działań UE w przestrzeni sprawiedliwości, wolności i bezpieczeństwa na okres 2010-2014. W Programie podkreślono jednak, że osoby pokrzywdzone potrzebują szczególnego wsparcia i ochrony prawnej; zaapelowano do Komisji i państw członkowskich o przeanalizowanie sposobów ulepszenia prawodawstwa i środków praktycznego wsparcia ochrony ofiar.

Z punktu widzenia problematyki udziału tłumacza istotne znaczenie miało przyjęcie Dyrektywy 2010/64/UE Parlamentu Europejskiego i Rady z dnia 20 paździer-

Sprawiedliwości i Spraw Wewnętrznych w dniu 3 grudnia 1998 r. (1999/C 19/01) (zwł. pkt 19 i 51); Komunikat Komisji z dnia 14 lipca 1999 r. „Ofiary przestępstw we Wspólnocie Europejskiej: refleksje w sprawie norm i działań” i rezolucja z dnia 15 czerwca 2000 r. w sprawie komunikatu; konkluzje z posiedzenia Rady Europejskiej w Tampere w dniach 15 i 16 października 1999 r. (zwł. pkt 32).

15 Dyrektywa Rady 2004/80/WE z dnia 29 kwietnia 2004 r. odnosząca się do kompensaty dla ofiar przestępstw, Dz.U. UE L 261 z 6.04.2004 r., s. 65-68.

16 Propozycja Decyzji Ramowej Rady w sprawie niektórych praw proceduralnych w postępowaniu karnym w Unii Europejskiej, COM (2004) 328, Bruksela 28.04.2004 - dostępna w bazie EUR-Lex.

17 Pkt 10.

18 Rezolucja Rady 2009/C 295/01 z dnia 30 listopada 2009 r. dotycząca harmonogramu działań mających na celu umocnienie praw procesowych osób podejrzanych lub oskarżonych w postępowaniu karnym, Dz.U. UE C 295 z 4.12.2009 r., s. 1-3.

19 Harmonogram działań mających na celu umocnienie praw procesowych osób podejrzanych lub oskarżonych w postępowaniu karnym.

20 Program Sztokholmski - otwarta i bezpieczna Europa dla dobra i ochrony obywateli, Dz.U. C 115 z 4.5 .2010 r., s. $1-38$. 
nika 2010 r. w sprawie prawa do thumaczenia ustnego i pisemnego w postępowaniu karnym $^{21}$. Ustanowiła ona wspólne minimalne zasady, które mają być stosowane w dziedzinach tłumaczenia pisemnego i ustnego w postępowaniu karnym oraz w postępowaniu służącym wykonaniu europejskiego nakazu aresztowania. Celem dyrektywy było zwiększenie ochrony praw jednostki poprzez zapewnienie podejrzanym lub oskarżonym prawa do tłumaczenia ustnego i thumaczenia pisemnego, z myślą o zagwarantowaniu im prawa do rzetelnego procesu sądowego. Jednak i w tym dokumencie nie przewidziano uprawnienia pokrzywdzonego do pomocy thumacza. Przy czym zaznaczono, że państwa członkowskie mają możliwość rozszerzenia praw w nim określonych, aby zapewnić wyższy poziom ochrony. Dyrektywa weszła w życie dnia 15 listopada 2010 r., a termin transpozycji przez państwa członkowskie wyznaczono na 27 października 2013 r. Nawiązanie do omawianej dyrektywy i zawartego w niej prawa do thumaczenia znajduje się także w kolejnych dyrektywach Parlamentu Europejskiego i Rady, np. wynikających ze wspomnianego wyżej harmonogramu ${ }^{22}$.

W rezolucji Rady z dnia 10 czerwca $2011 \mathrm{r}^{23}$ wyraźnie zaznaczono, że aktywna ochrona ofiar przestępstw stanowi wysoki priorytet dla UE i państw członkowskich. Podkreślono, że w obszarze ochrony ofiar przestępstw należy przyjąć podobne podejście, jak w kwestii umocnienia praw procesowych osób podejrzanych lub oskarżonych, gdzie już poczyniono znaczne postępy. Harmonogram ${ }^{24}$, stanowiący załącznik do rezolucji, zawierał wykaz środków służących wzmocnieniu ochrony ofiar. Wspieranie zapewniania thumaczenia ustnego i pisemnego $\mathrm{w}$ postępowaniu karnym wskazano jako jeden z celów ogólnych, osiągnięciu których mają służyć działania na szczeblu unijnym ukierunkowane na zwiększenie praw i ochrony ofiar. Wśród środków, które miały służyć realizacji celów wskazanych w harmonogramie, wymieniono także dyrektywę mającą zastąpić, wspomnianą już, decyzję ramową z $2001 \mathrm{r}$.

I tak, 25 października 2012 r. uchwalono Dyrektywę Parlamentu Europejskiego i Rady ustanawiającą normy minimalne w zakresie praw, wsparcia i ochrony ofiar przestępstw oraz zastępującą decyzję ramową Rady ${ }^{25}$. Jako jej cel wskazano zapewnienie, by ofiary przestępstw otrzymały odpowiednie informacje, wsparcie, ochronę

Dyrektywa 2010/64/UE Parlamentu Europejskiego i Rady z dnia 20 października 2010 r. w sprawie prawa do tłumaczenia ustnego i pisemnego w postępowaniu karnym, Dz.U. UE L 280 z 26.10.2010 r., s. 1-7.

Zob. Dyrektywa 2012/13/UE Parlamentu Europejskiego i Rady z dnia 22 maja 2012 r. w sprawie prawa do informacji w postępowaniu karnym, Dz.U. UE L 142 z 1.6.2012 r., s. 1-10 oraz Dyrektywa 2013/48/UE Parlamentu Europejskiego i Rady z dnia 22 października 2013 r. w sprawie prawa dostępu do adwokata w postępowaniu karnym i w postępowaniu dotyczącym europejskiego nakazu aresztowania oraz w sprawie prawa do poinformowania osoby trzeciej o pozbawieniu wolności i prawa do porozumiewania się z osobami trzecimi i organami konsularnymi w czasie pozbawienia wolności, Dz.U. UE L 294 z 6.11.2013 r., s. 1-12.

23 Rezolucja Rady 2011/C 187/01 z dnia 10 czerwca 2011 r. w sprawie harmonogramu działań na rzecz zwiększania praw i ochrony ofiar, zwłaszcza w postępowaniu karnym Dz.U. UE C 187 z 28.06.2011 r., s. 1-5.

24 Harmonogram działań na rzecz zwiększania praw i ochrony ofiar, zwłaszcza w postępowaniu karnym.

25 Dyrektywa 2012/29/UE Parlamentu Europejskiego i Rady z dnia 25 października 2012 r. ustanawiająca normy minimalne w zakresie praw, wsparcia i ochrony ofiar przestępstw oraz zastępująca decyzję ramową Rady 2001/220/WSiSW, Dz.U. UE L 315 z 14.11.2012 r., s. 57-73. 
oraz by mogły uczestniczyć w postępowaniu karnym. Dyrektywa stanowi jak dotąd najważniejszy dokument, z punktu widzenia prawa pokrzywdzonego do pomocy thumacza.

W stanowisku RP ${ }^{26}$ wyraźnie podkreślono, że prawo do tłumaczenia należy do najważniejszych elementów dyrektywy. Zaznaczono jednak, że uprawnienia należy dostosować do roli pokrzywdzonego w postępowaniu karnym (usytuowania jako strony bądź uczestnika postępowania), a prawo do thumaczenia nie powinno być rozszerzane w sposób sprzeczny z interesem pokrzywdzonego (szczególnie wtedy, gdy nie jest on zainteresowany uczestnictwem w postępowaniu i jego przebiegiem). Podkreślono także, że zakres tłumaczenia nie powinien wykraczać poza zakres analogicznych obowiązków spoczywających na organach wymiaru sprawiedliwości w odniesieniu do oskarżonych.

Już w samej dyrektywie wskazano na obowiązek zapewniania, by ofiara była rozumiana podczas postępowania. Zaznaczono, że osoby takie muszą mieć możliwość wyjaśnienia okoliczności przestępstwa i przedstawienia dowodów w sposób zrozumiały dla właściwych organów; muszą mieć także możliwość korzystania z przysługujących im praw.

W art. 7 dyrektywy, zatytułowanym ,prawo do tłumaczenia ustnego i pisemnego", przewidziano obowiązek państw członkowskich zapewnienia ofiarom, które nie rozumieją języka postępowania karnego lub nim nie mówią, możliwości skorzystania (na wniosek) z bezpłatnego tłumaczenia ustnego. Możliwość taka ma być zapewniona co najmniej podczas rozmów z nimi lub przesłuchań w toku postępowania karnego przed organami dochodzeniowymi lub sądowymi (w tym podczas przesłuchania przez policję) oraz w związku z ich czynnym udziałem w rozprawie sądowej i niezbędnych posiedzeniach.

$\mathrm{Na}$ państwa członkowskie nałożono także obowiązek zapewnienia ofiarom, które nie rozumieją języka danego postępowania karnego lub w nim nie mówią, na wniosek, bezpłatnego tłumaczenia pisemnego na język, który jest dla nich zrozumiały, informacji niezbędnych do skorzystania z przysługujących im praw w postępowaniu karnym, w zakresie, w jakim informacje takie są udostępniane ofierze. Takie thumaczenie ma objąć co najmniej decyzję kończącą postępowanie karne związane z przestępstwem popełnionym na szkodę ofiary. Na wniosek ofiary, obejmuje także uzasadnienie decyzji albo krótkie jego streszczenie. Ofiarom uprawnionym do uzyskania informacji o dacie i miejscu rozprawy, które nie rozumieją języka postępowania, przysługuje także uprawnienie do otrzymania, na wniosek, tłumaczenia tych informacji. Ponadto, mogą złożyć wniosek o uznanie dokumentu za istotny,

26 Stanowisko RP przygotowane w związku z art. 7 ustawy z dnia 8 października 2010 r. o współpracy Rady Ministrów z Sejmem i Senatem w sprawach związanych z członkostwem Rzeczypospolitej Polskiej w Unii Europejskiej Dz.U. Nr 213, poz. 1395 dotyczącym Dyrektywy Parlamentu Europejskiego i Rady ustanawiającej normy minimalne w zakresie praw, wsparcia i ochrony ofiar przestępstw - dostępne na oficjalnej stronie internetowej Ministerstwa Sprawiedliwości - www.ms.gov.pl 
przy czym nie ma wymogu tłumaczenia fragmentów istotnych dokumentów, nie mających znaczenia dla umożliwienia ofiarom czynnego udziału w postępowaniu karnym. O ile nie wpłynie ono negatywnie na rzetelność postępowania, zamiast tłumaczenia pisemnego można zapewnić tłumaczenie ustne istotnych dokumentów.

Na państwa członkowskie nałożono obowiązek zapewnienia, by właściwe organy dokonały oceny, czy pokrzywdzeni potrzebują tłumaczenia. Ofiarom przysługuje natomiast uprawnienie do zaskarżenia decyzji o odmowie zapewnienia thumaczenia. Wyraźnie podkreślono jednak, że zarówno tłumaczenie, jak i rozpoznanie skargi na decyzję o odmowie zapewnienia thumaczenia, nie mogą wydłużać (w sposób nieuzasadniony) postępowania karnego.

Dyrektywa weszła w życie 15 listopada 2012 r., a państwa członkowskie mają dokonać jej transpozycji do dnia 16 listopada $2015 \mathrm{r}$.

$\mathrm{Z}$ analizy powyższych regulacji wyraźnie wynika, że w przepisach UE przewidziano prawo podejrzanego i oskarżonego do pomocy tłumacza. I chociaż pojawiają się dokumenty przewidujące uprawnienie pokrzywdzonego do takiej pomocy, w dalszym ciągu zdecydowanie bardziej akcentowane jest uprawnienie oskarżonego. Jak zaznaczono we wspomnianej rezolucji z $2011 \mathrm{r}$., w obszarze ochrony praw ofiar przestępstw należy przyjąć podobne podejście, jak w kwestii umocnienia praw procesowych osób podejrzanych lub oskarżonych, czemu służą właśnie m.in. uprawnienia przewidziane $\mathrm{w}$ dyrektywie z $2012 \mathrm{r}$.

\section{Prawo pokrzywdzonego do pomocy tłumacza w polskim kodeksie postępowania karnego}

Problematyka udziału thumacza w postępowaniu karnym uregulowana jest przede wszystkim $\mathrm{w}$ art. 72, art. 204 i art. 618 k.p.k. Przy czym przepis art. 72 traktuje jedynie o uprawnieniu oskarżonego, a przepis art. 618 o wydatkach Skarbu Państwa w kontekście należności tłumaczy.

Uprawnienie pokrzywdzonego do udziału thumacza przewiduje art. 204 k.p.k. W myśl $\S 1$ obowiązek wezwania thumacza pojawia się, gdy zachodzi potrzeba przesłuchania osoby nie władającej językiem polskim. Jak wyraźnie wskazuje się $\mathrm{w}$ orzecznictwie ${ }^{27}$, to nie tylko osoba, która w ogóle nie zna języka polskiego, ale także ta, która nie rozumie w dostatecznym stopniu zadawanych jej pytań albo też, w wyniku słabej znajomości danego języka, nie może swobodnie sformułować swoich myśli. Podnosi się, że na gruncie przepisów k.p.k. konieczność wezwania thumacza powstaje wówczas, gdy dana osoba nie może pojąć znaczenia i sensu dokonywanych czynności procesowych albo nie ma możliwości wysłowienia się w ję- 
Wpływ regulacji Unii Europejskiej na prawo pokrzywdzonego do pomocy tłumacza...

zyku polskim, chyba że istnieją uzasadnione podstawy do przekonania, że wbrew deklaracjom, w wystarczającym stopniu posługuje się tym językiem. Przedmiotowy przepis nie wyjaśnia pojęcia ,niewładania językiem polskim”. Nie stawia on także wymagania, aby tłumaczenie było dokonywane na język ojczysty. Procedura karna stawia jedynie warunek osiągnięcia porozumienia się, do czego wystarcza używanie języka zrozumiałego dla wypowiadających się osób.

Jednak już $\S 2$ tego artykułu traktuje o uprawnieniu jedynie oskarżonego. K.p.k. nie określa bliżej pozycji tłumacza. § 3 omawianego artykułu ogranicza się do stwierdzenia, że do tłumacza odpowiednio stosuje się przepisy dotyczące biegłych. K. Boratyńska zauważa ${ }^{28}$, że dotyczy to w szczególności wyłączenia, zakazów dowodowych oraz przyrzeczenia.

\section{Implementacja regulacji Unii Europejskiej na gruncie kodeksu postępowania karnego}

Częściowego wdrożenia dyrektyw Parlamentu Europejskiego i Rady: 2010/64/ UE i 2012/13/UE dokonała w zakresie swojej regulacji Ustawa z dnia 27 września 2013 r. ${ }^{29}$ Zmieniono nią treść art. $72 \S 2^{30}$, traktującego jednak jedynie o uprawnieniu oskarżonego. Tym samym znacznie to uprawnienie rozszerzono i zagwarantowano oskarżonemu możliwość porozumiewania się z obrońcą, do czego zobligowane zostały państwa członkowskie wspomnianymi regulacjami unijnymi. Artykuł w tym brzmieniu obowiązuje od 9 listopada $2013 \mathrm{r}$.

Wspomniana nowelizacja wprowadziła także istotną zmianę, z punktu widzenia omawianej problematyki, w treści art. 204 k.p.k. W § 2 słowo „oskarżonego” zastąpiono słowem „strony”, wobec czego otrzymał on brzmienie: „Należy również wezwać tłumacza, jeżeli zachodzi potrzeba przełożenia na język polski pisma sporządzonego w języku obcym lub odwrotnie albo zapoznania strony $\mathrm{z}$ treścią przeprowadzonego dowodu". Zmiana ta stanowi krok naprzód w umacnianiu pozycji pokrzywdzonego w procesie karnym. Przepis będzie obowiązywał w nowym brzmieniu od dnia 1 lipca $2015 \mathrm{r}$.

\section{Wnioski i postulaty de lege ferenda}

Analiza przepisów k.p.k. przewidujących udział tłumacza w postępowaniu karnym nie pozostawia wątpliwości, że w dalszym ciągu zdecydowanie bardziej akcentowane jest uprawnienie oskarżonego, a zupełnie pominięte zostało uprawnienie

\footnotetext{
28 K. Boratyńska, (w:) K. Boratyńska, A. Górski, A. Sakowicz, A. Ważny, op. cit., s. 418.

29 Ustawa z dnia 27 września 2013 r. o zmianie ustawy - Kodeks postępowania karnego oraz niektórych innych ustaw, Dz.U. z 2013 r., poz. 1247.

30 Dodano zdanie: „Na wniosek oskarżonego lub jego obrońcy tłumacza należy wezwać również w celu porozumienia się oskarżonego z obrońcą w związku z czynnością, do udziału w której oskarżony jest uprawniony”.
} 
pokrzywdzonego występującego w charakterze strony procesowej, kiedy nie włada on językiem polskim. W doktrynie wskazuje się, że dochodzi do asymetrii uprawnień pokrzywdzonego i oskarżonego, a zarówno regulacje unijne, jak i - wspomniany na wstępie - art. $2 \S 1$ pkt 3 k.p.k. wyraźnie nakazują uwzględniać prawnie chronione interesy pokrzywdzonego. Faktem jest, że brak takiego uprawnienia pokrzywdzonego w k.p.k. nie oznacza braku takiego uprawnienia w przepisach prawa w ogóle ${ }^{31}$. Uprawnienie takie przysługuje pokrzywdzonemu także na mocy art. $5 \S 2$ ustawy Prawo o ustroju sądów powszechnych ${ }^{32}$, ale tylko w postępowaniu przed sądem. Nie ma on takiego prawa w postępowaniu przygotowawczym, w którym przecież podejmowane są istotne czynności także dla pokrzywdzonego, niejednokrotnie przesądzające o dalszych losach postępowania ${ }^{33}$. A jak słusznie zauważa S. Stachowiak $^{34}$, jednym z podstawowych zadań postępowania karnego jest troska o ochronę interesów pokrzywdzonego.

Co prawda przepis art. $204 \S 1$ k.p.k. dotyczy także pokrzywdzonego, nie traktuje on jednak o pokrzywdzonym występującym w charakterze strony procesowej. Jak słusznie zauważa S. Stachowiak ${ }^{35}$,uprawnienie pokrzywdzonego występującego $\mathrm{w}$ charakterze strony $\mathrm{w}$ procesie karnym do korzystania $\mathrm{z}$ pomocy thumacza pozostaje w »głębokim cieniu« regulacji prawnych, a tak naprawdę jest w nich nieobecne. Kodeks postępowania karnego z 1997 r. w żadnym z przepisów nawet nie wspomina o takim uprawnieniu". A już $\S 2$ tego artykułu, w kształcie obowiązującym obecnie, traktuje o uprawnieniu jedynie oskarżonego. Jak zauważył S. Stachowiak $^{36}$,uderza $\mathrm{w}$ tym rozwiązaniu nade wszystko to, że ustawodawca jedynie po stronie oskarżonego przewiduje obowiązek zapoznania go z treścią przeprowadzonego dowodu, w sytuacji kiedy nie włada on językiem polskim". Stąd też z aprobatą należy przyjąć zmianę treści przepisu art. 204 § 2 k.p.k., która bez wątpienia służy umocnieniu pozycji pokrzywdzonego w procesie karnym.

Nie sposób nie zgodzić się z B. Zygmontem ${ }^{37}$, który podkreśla, że obwinionemu i pokrzywdzonemu powinny zostać niezwłocznie przyznane identyczne gwarancje procesowe, jakie przysługują oskarżonemu. Bowiem dopiero wówczas zostaną $\mathrm{w}$ tym zakresie zrealizowane $\mathrm{w}$ całości zobowiązania prawnomiędzynarodowe

Zob. np. § 167 ust. 2 Rozporządzenia Ministra Sprawiedliwości z dnia 24 marca 2010 r.: Regulamin wewnętrznego urzędowania powszechnych jednostek organizacyjnych prokuratury (Dz.U. $2014 \mathrm{Nr} 49$, poz. 296, tj. Dz.U. 2014, poz. 144) oraz § 111 Zarządzenia nr 1426 Komendanta Głównego Policji z dnia 23 grudnia 2004 r. w sprawie metodyki wykonywania czynności dochodzeniowo-śledczych przez służby policyjne wyznaczone do wykrywania przestępstw i ścigania ich sprawców, Dz. Urz. KGP 05.1.1. Ustawa z dnia 27 lipca 2001 r. Prawo o ustroju sądów powszechnych, Dz.U. z 2001 r. Nr 98, poz. 1070, tj. z dnia 30 stycznia 2013 r., Dz.U. z 2013 r., poz. 427.

33 R. Stefański, op. cit., s. 377.

34 S. Stachowiak, Uprawnienie pokrzywdzonego do korzystania z pomocy tłumacza w polskim procesie karnym, „Prokuratura i Prawo” 2000, nr 12, s. 8.

35 Ibidem, s. 14

36 Ibidem, s. 12.

37 B. Zygmont, Prawo do korzystania z bezpłatnej pomocy tłumacza w postępowaniu karnym w świetle standardów europejskich, „Państwo i Prawo” 2004, nr 7, s. 87. 
przyjęte przez Polskę. Słusznie wskazuje P. Wiliński ${ }^{38}$, że idea, którą wyraża rzetelny proces, nie pozwala wybiórczo określać adresatów. Proces ma być rzetelny dla wszystkich, a nie jedynie dla wybranej strony postępowania. Nie sposób nie zgodzić się z M. Żbikowską ${ }^{39}$, że lojalność organów procesowych nie może być różna w zależności od tego, z jakim uczestnikiem postępowania mamy do czynienia, a zasada lojalności procesowej w jednakowym stopniu odnosi się zarówno do oskarżonego, jak i pokrzywdzonego. Stąd też ich uprawnienia powinny być równorzędne i przewidziane w aktach o tej samej pozycji hierarchicznej (w k.p.k.).

Na konieczność taką wskazał m.in. senator R. Knosala w swoim oświadczeniu skierowanym do ministra sprawiedliwości ${ }^{40}$, gdzie zauważył, że w k.p.k., który jest zasadniczym aktem regulującym proces karny, zaznaczono jedynie prawo oskarżonego do pomocy tłumacza, zaniedbując osobę pokrzywdzoną. Podniósł, że brak uregulowania dotyczącego postępowania przygotowawczego w akcie o randze ustawy godzi w zasadę równouprawnienia stron w postępowaniu karnym. W odpowiedzi na oświadczenie ${ }^{41}$ wskazano, że chociaż uprawnienia osoby podejrzanej i pokrzywdzonej w postępowaniu przygotowawczym w zakresie korzystania z pomocy tłumacza są identyczne (mimo że wynikają z przepisów o odmiennej randze w hierarchii aktów prawnych), to w postępowaniu przed sądem są one istotnie zróżnicowane. I w tym względzie za słuszny uznano ,pogląd o niezachowaniu zasady »równości broni« pomiędzy stronami w odniesieniu do możliwości korzystania z pomocy tłumacza, na etapie postępowania sądowego, przez osoby niewładające w wystarczającym stopniu językiem polskim". Zauważono, że umożliwienie korzystania z tych uprawnień także pokrzywdzonemu wydaje się celowe, by urzeczywistniać naczelne zasady procesu (zwłaszcza kontradyktoryjności, równouprawnienia stron, czy prawdy materialnej). Zwrócono jednak uwagę na fakt, że ze względu na odmienność obowiązków procesowych pokrzywdzonego i oskarżonego, symetryczne odwzorowywanie uprawnień obu stron nie byłoby celowe i mogłoby spowodować wzrost kosztów postępowania. Stąd też wskazano na potrzebę poddania tejże problematyki pogłębionej analizie. Zobowiązano się także do podjęcia prac w Ministerstwie Sprawiedliwości mających na celu wypracowanie propozycji zmian poszerzających uprawnienia pokrzywdzonego do korzystania z pomocy tłumacza w toku postępowania karnego.

W świetle powyższych rozważań można stwierdzić, że istnieje wyraźna potrzeba przepisu, który przyznałby pokrzywdzonemu prawo do korzystania z bezpłatnej po-

38 P. Wiliński, O koncepcji rzetelnego procesu karnego, (w:) J. Skorupka, W. Jasiński, Rzetelny proces karny. Materiały konferencji naukowej Trzebieszowice 17-19 września 2009 r., Warszawa 2010, s. 174-175.

39 M. Żbikowska, O projektowanych zmianach zasady lojalności procesowej, „Prokuratura i Prawo” 2012, nr 9, s. 96.

40 Oświadczenie senatora Ryszarda Knosali skierowane do ministra sprawiedliwości Krzysztofa Kwiatkowskiego na 64. posiedzeniu Senatu w dniu 4 listopada 2010 r. - dostępne na oficjalnej stronie internetowej Senatu RP - www. senat.gov.pl

41 Odpowiedź Zbigniewa Wrony, Podsekretarza Stanu z dnia 21 grudnia 2010 r. na oświadczenie senatora Ryszarda Knosali skierowane do ministra sprawiedliwości Krzysztofa Kwiatkowskiego na 64. posiedzeniu Senatu w dniu 4 listopada 2010 r. - dostępna na oficjalnej stronie Senatu RP - www.senat.gov.pl 
mocy thumacza adekwatnie, jak ma to miejsce w przypadku oskarżonego. Prawdopodobnym jest, że będą następować nowelizacje k.p.k. mające na celu przyznanie takiego uprawnienia, wynikające z konieczności dostosowania ustawodawstwa polskiego do standardów postępowania karnego kształtowanych przez regulacje UE. Jak słusznie zauważa H. Paluszkiewicz ${ }^{42}$, „stworzenie dla ofiar przestępstw skutecznych mechanizmów ochrony i pomocy karnoprocesowej staje się wyrazistą tendencją w polityce karnej Unii Europejskiej, jak też poszczególnych państw członków Unii". A jednym z najważniejszych elementów takiej ochrony jest uprawnienie do pomocy thumacza. 
Wpływ regulacji Unii Europejskiej na prawo pokrzywdzonego do pomocy tłumacza...

\section{THE IMPACT OF THE EUROPEAN UNION LEGISLATION ON THE RIGHT OF A VICTIM TO INTERPRETATION AND TRANSLATION IN THE POLISH CRIMINAL PROCEDURE}

The European Union has made support to victims of crime a priority. Steps are taken to ensure that their needs are met. Both legislative and practical measures have been put in place to provide an adequate level for the protection of victim's rights. One of the most important rights provided for is the right to interpretation and translation.

The paper presents and discusses the impact of the European Union legislation on the right of a victim to interpretation and translation in the Polish criminal procedure. It describes both EU and domestic provisions concerning the right of a victim to translation and interpretation as well as amendments to domestic regulations resulting from implementation of EU legislation.

Keywords: victim, translator, interpreter, translation, European Union, criminal procedure, right to interpretation/translation 